\title{
Volatile organic compounds released from thermal drying of sewage sludge
}

\author{
M. F. Gomez-Rico, A. Fullana \& R. Font \\ Department of Chemical Engineering, University of Alicante, Spain
}

\begin{abstract}
Thermal drying of sewage sludge is a treatment to obtain a material that can be used as co-fuel for some chemical industries, but some volatile organic compounds (VOCs) can be emitted and consequently must be considered. In this work the emissions of these VOCs were studied. The sewage sludge produced by a domestic water treatment plant was dried in a simple laboratory scale distillation/evaporation apparatus at different temperatures $(80,90,100$ and $120^{\circ} \mathrm{C}$ ). The sludge was heated and a flow of air released water and volatile compounds. The water was condensed and separated, and the VOCs were analysed in the resultant gas fraction. More than forty compounds were identified and the total yield ranged from 545 to $591 \mathrm{mg} \mathrm{kg}^{-1}$ dry weight, without significant differences for the temperatures used. The compounds with the highest yields were dimethyl disulfide, toluene, dimethyl trisulfide and 1,2,4trimethylbenzene, with great differences in yields from the rest of the compounds found. Between the compounds identified, several types were found: aliphatic hydrocarbons, aromatic hydrocarbons, halogenated or not, and compounds with sulphur. Since most of the identified VOCs are carcinogenic, toxic or harmful by inhalation, there is a need to control the emitted gases from thermal drying.
\end{abstract}

Keywords: VOCs, thermal drying, sewage sludge, temperature.

\section{Introduction}

The sewage sludge that leaves the wastewater treatment plant has a high content of water (up to $90 \%$ ). The elimination of this water means a great reduction in volume that involves lower costs of transport and dumping of the sludge. Moreover, mechanical dehydration by filter press, centrifuges, etc. is not always enough to satisfy the environmental regulations and use the sludge for energy 
valorisation (the water content reduces the calorific value of the sludge, as it absorbs heat for its vaporisation in the thermal processes). For these reasons, an additional step of thermal drying is usually required for the sludge after the treatment at the WWTP for its later use.

The thermal drying of sludge can involve an emission of volatile organic compounds (VOCs), which were contained in the sludge and evaporate. On the one hand, they could come from the wastewater that enters the WWTP, which can include water from industry. On the other hand, they could be generated during the metabolic activity of the bacteria, which decompose the sludge organic matter in the processes performed at the WWTP, appearing as intermediate metabolites [1].

Several authors studied the occurrence of VOCs in sewage sludge $[2,3]$, as well as in different parts of the WWTPs [4]: in the inlet wastewater, in water after some treatments and in the environmental air. These authors reported high concentrations of toluene and xylenes. Moreover, some of the VOCs identified in sludge could be carcinogenic, such as 1,4-dichlorobenzene.

Nevertheless, no study has been found with regard to VOCs released during thermal drying of sludge. There are only studies related to emissions during dewatering processes, although the temperatures are much lower than for drying and therefore the emissions due to the VOCs vaporisation are supposedly lower.

The drying plants normally include deodorization systems to avoid the emission of VOCs to the atmosphere. However, the efficiency of these systems is not controlled and therefore pollutants could be released to the environment.

The aim of this work was to study the emissions of VOCs during the thermal drying of sludge with a simple system of distillation in the laboratory and at different temperatures, usual at the thermal drying plants. The knowledge of the compounds involved and their levels permit the assessment of the need to control the emissions at the drying plants.

\section{Experimental}

\subsection{Sewage sludge}

The sewage sludge used was produced by a domestic water treatment plant located in Alcoi, an urban area of the Region of Valencia (SE Spain), with a water flow of $19600 \mathrm{~m}^{3} \mathrm{~d}^{-1}$ that includes a certain amount from industry. The main type of industry in the area is textile. The sludge was treated by anaerobic digestion and filter band dehydration.

\subsection{Set up for drying}

A simple system of distillation made of glass pieces was used, and a diagram of this can be observed in fig. 1 . In this system, around $50 \mathrm{~g}$ of sludge sample, previously mixed with $100 \mu \mathrm{L}$ of an internal standard, was heated to release water and VOCs. A flow of $1 \mathrm{~mL} \mathrm{~min}^{-1}$ of air passed through the sample to carry them to a condenser. Water was condensed (around $35 \mathrm{~g}$ ) and $0.1 \mathrm{~mL} \mathrm{~min}^{-1}$ of the air passed through a sorbent $\left(\right.$ Tenax ${ }^{\circledR}-\mathrm{GC}$, Gerstel) to collect the organic 
compounds, whereas $0.9 \mathrm{~mL} \min ^{-1}$ (the rest of the air, considering an insignificant increase in volume of the initial air) was disposed off to avoid a great pressure drop through the Tenax ${ }^{\circledR}$. Gas sampling followed the US EPA method 0031 [5]. The experiments were carried out at four different temperatures: $80,90,100$ and $120^{\circ} \mathrm{C}$ (measured in the wall of the sample receptacle). The process took $5-8 \mathrm{~h}$ until complete dryness, depending on the temperature.

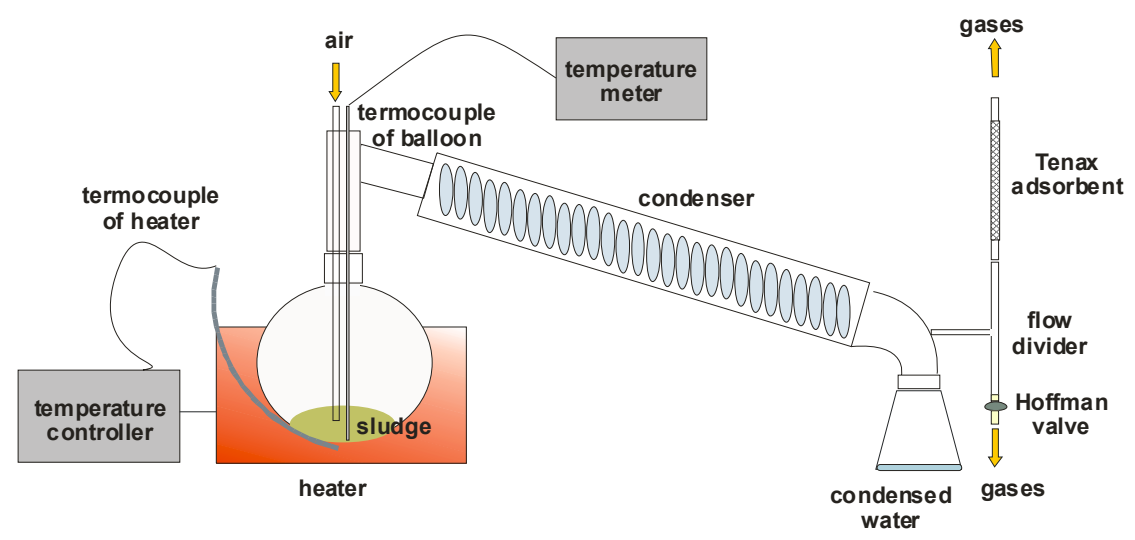

Figure 1: Diagram of the drying system.

The analysis of the compounds collected at the sorbent from the gas fraction was done by thermal desorption and gas chromatography/mass spectrometry (GC/MS), following US EPA methods 5041A [6] and 8260B [7], respectively. For GC, a column DB-624 (30 m in length $x 0.53 \mathrm{~mm}$ I.D.) was used with an injector CIS 4+ (PTV). For MS, a positive electronic impact (EI+) source was employed with the scanning method (SCAN) for compounds for which standards were not available, and selective ion register (SIR) for compounds with available external standards. In the first case, the identification was done by comparison of the mass spectra with the NIST database and the quantification was semiquantitative and using the response factor of the internal standard with the nearest retention time. In the second case, the internal and external standards were used. One blank sample was also analysed to check the contamination of the material used.

The internal standard comprised two mixtures (1:1 in volume) of deuterated and fluorinated volatile compounds (8260A Internal Standards Mix and 8260A Surrogate Standards Mix, $250 \mu \mathrm{g} \mathrm{mL}^{-1}$ each one, Supelco). The external standards were a mixture of 54 VOCs (502/524 Volatiles Organic Calibration Mix, $200 \mu \mathrm{g} \mathrm{mL}^{-1}$, Supelco) and dimethyl disulfide (pure, Merck).

\section{Results}

The yields of compounds found in the experiments at four different temperatures can be observed in table 1 . The experiment carried out at $100{ }^{\circ} \mathrm{C}$ was replicated, 
Table 1: $\quad$ Yields of compounds analysed from the gas fraction at different temperatures with respect to dry weight (d.w.) of sludge.

\begin{tabular}{|c|c|c|c|c|}
\hline \multirow[t]{2}{*}{ COMPOUND } & \multicolumn{4}{|c|}{$\begin{array}{c}\text { YIELD } \\
\text { (mg kg-1 d.w.) }\end{array}$} \\
\hline & $80^{\circ} \mathrm{C}$ & $90^{\circ} \mathrm{C}$ & $100^{\circ} \mathrm{C}$ & $120^{\circ} \mathrm{C}$ \\
\hline Dibromomethane $^{\mathrm{a}}$ & nd & nd & nd & nd \\
\hline Bromodichloromethane $^{\mathrm{a}}$ & nd & nd & nd & nd \\
\hline trans-1,3-Dichloropropene ${ }^{\mathrm{a}}$ & nd & nd & nd & nd \\
\hline Dimethyl disulfide ${ }^{\mathrm{a}, \mathrm{b}}$ & 176 & 230 & 212 & 143 \\
\hline Toluene $^{\mathrm{a}, \mathrm{b}}$ & 97 & 102 & 98 & 34 \\
\hline cis-1,3-Dichloropropene ${ }^{\mathrm{a}}$ & nd & nd & nd & nd \\
\hline $1,1,2-$ Trichloroethane $^{\mathrm{a}}$ & nd & nd & nd & nd \\
\hline Tetrachloroethene $^{\mathrm{a}}$ & nd & nd & nd & nd \\
\hline 1,3-Dichloropropane ${ }^{a}$ & nd & nd & nd & nd \\
\hline Dibromochloromethane $^{a}$ & nd & nd & nd & nd \\
\hline 1,2-Dibromoethane ${ }^{\mathrm{a}}$ & nd & nd & nd & nd \\
\hline n-Hexanal ${ }^{\mathrm{b}}$ & 2.4 & 2.7 & 3.0 & 17 \\
\hline Chlorobenzene $^{\mathrm{a}, \mathrm{c}}$ & 0.039 & 0.032 & 0.043 & 0.10 \\
\hline $1,1,1,2$-Tetrachloroethane ${ }^{\mathrm{a}}$ & nd & nd & nd & nd \\
\hline Ethylbenzene $^{\mathrm{a}, \mathrm{b}}$ & 0.95 & 0.48 & 0.37 & 0.44 \\
\hline m-Xylene + p-xylene ${ }^{a, b}$ & 3.3 & 1.9 & 1.9 & 4.2 \\
\hline Nonane $^{b}$ & 9.5 & 5.5 & 4.1 & 8.9 \\
\hline Styrene $^{\mathrm{a}, \mathrm{c}}$ & 0.99 & 0.59 & 0.44 & 0.78 \\
\hline o-Xylene ${ }^{\mathrm{a}, \mathrm{c}}$ & 0.69 & 0.36 & 0.29 & 0.47 \\
\hline Bromoform $^{\mathrm{a}}$ & nd & nd & nd & nd \\
\hline Heptanal $^{\mathrm{c}}$ & 1.6 & 1.3 & 1.5 & 7.5 \\
\hline Isopropylbenzene ${ }^{\mathrm{a}, \mathrm{c}}$ & 0.38 & 0.22 & 0.21 & 0.30 \\
\hline Bromobenzene $^{a}$ & nd & nd & nd & nd \\
\hline 1,2,3-Trichloropropane ${ }^{\mathrm{a}}$ & nd & nd & nd & nd \\
\hline $1,1,2,2$-Tetrachloroethane ${ }^{a}$ & nd & nd & nd & nd \\
\hline 2-Chlorotoluene ${ }^{\mathrm{a}}$ & nd & nd & nd & nd \\
\hline n-Propylbenzene ${ }^{a, b}$ & 3.0 & 2.1 & 2.0 & 2.6 \\
\hline Ethyltoluenes + undeter. trimethylbenzene ${ }^{b}$ & 17 & 9.9 & 9.5 & 17 \\
\hline
\end{tabular}


Table 1: Continued.

\begin{tabular}{|c|c|c|c|c|}
\hline \multirow[t]{2}{*}{ COMPOUND } & \multicolumn{4}{|c|}{$\begin{array}{c}\text { YIELD } \\
\text { (mg kg-1 d.w.) }\end{array}$} \\
\hline & $80^{\circ} \mathrm{C}$ & $90^{\circ} \mathrm{C}$ & $100^{\circ} \mathrm{C}$ & $120^{\circ} \mathrm{C}$ \\
\hline 4-Chlorotoluene ${ }^{\mathrm{a}}$ & nd & nd & nd & nd \\
\hline 1,3,5-Trimethylbenzene $\mathrm{a}^{\mathrm{a}, \mathrm{b}}$ & 6.2 & 34 & 31 & 48 \\
\hline Dimethyl trisulfide ${ }^{\mathrm{b}}$ & 90 & 61 & 54 & 67 \\
\hline Decane $^{b}$ & 47 & 38 & nd & nd \\
\hline tert-Butylbenzene + p-isopropyltoluene $e^{\mathrm{a}, \mathrm{c}}$ & 16 & 11 & 9.7 & 15 \\
\hline Benzaldehyde $^{c}$ & nd & nd & 25 & 21 \\
\hline 1,2,4-Trimethylbenzene $e^{\mathrm{a}, \mathrm{b}}$ & 60 & 42 & 38 & 66 \\
\hline Undetermined methyldecane $^{c}$ & 0.37 & 0.29 & 0.36 & 0.55 \\
\hline sec-Butylbenzene $\mathrm{a}^{\mathrm{a}, \mathrm{c}}$ & 0.90 & 0.48 & 0.39 & 0.15 \\
\hline 1,3-Dichlorobenzene ${ }^{\mathrm{a}}$ & nd & nd & nd & nd \\
\hline 1,4-Dichlorobenzene $e^{\mathrm{a}, \mathrm{b}}$ & 0.12 & 0.10 & 0.096 & 0.032 \\
\hline Limonene $^{\mathrm{b}}$ & 6.2 & 4.5 & 1.6 & 4.6 \\
\hline Diethylbenzenes + ethyldimethylbenzene undet. ${ }^{b}$ & 3.0 & 2.0 & 2.0 & 4.0 \\
\hline 1,2-Dichlorobenzene $e^{\mathrm{a}, \mathrm{b}}$ & 2.9 & 2.0 & 2.0 & 3.1 \\
\hline Propyltoluenes $^{\mathrm{b}}$ & 2.7 & 2.3 & 2.3 & 4.7 \\
\hline n-Butylbenzene $e^{\mathrm{a}, \mathrm{b}}$ & 0.82 & 0.32 & 0.35 & 0.85 \\
\hline Ethylxylenes $^{\mathrm{b}}$ & 2.6 & 2.3 & 2.6 & 4.9 \\
\hline Undecane $^{\mathrm{b}}$ & 5.7 & 4.6 & 5.6 & 11 \\
\hline $\mathrm{Phenol}^{\mathrm{c}}$ & 0.98 & 0.60 & 0.62 & 0.79 \\
\hline 1,2-Dibromo-3-chloropropane ${ }^{a}$ & nd & nd & nd & nd \\
\hline Undetermined nonanone $^{c}$ & 0.48 & 0.50 & 0.77 & 3.1 \\
\hline Dichlorotoluenes $^{\mathrm{b}}$ & 12 & 9.7 & 13 & 32 \\
\hline Undetermined saturated hydrocarbons $\mathrm{C}_{12}$ & 2.2 & 1.9 & 2.4 & 3.1 \\
\hline Dodecane $^{b}$ & 4.2 & 3.5 & 4.6 & 8.3 \\
\hline 1,2,4-Trichlorobenzene $\mathrm{e}^{\mathrm{a}, \mathrm{b}}$ & nd & 0.15 & 0.043 & 0.12 \\
\hline Undetermined saturated hydrocarbons $\mathrm{C}_{13}$ & 1.6 & 1.9 & 2.2 & 3.3 \\
\hline Naphthalene $^{\mathrm{a}, \mathrm{c}}$ & 0.56 & 0.60 & 0.74 & 1.7 \\
\hline Hexachlorobutadiene $^{a}$ & nd & 0.11 & nd & nd \\
\hline 1,2,3-Trichlorobenzene $\mathrm{e}^{\mathrm{a}, \mathrm{b}}$ & nd & 0.21 & 0.046 & 0.12 \\
\hline
\end{tabular}


Table 1: Continued.

\begin{tabular}{|l|c|c|c|c|}
\hline \multirow{2}{*}{ COMPOUND } & \multicolumn{4}{c|}{$\begin{array}{c}\text { YIELD } \\
\text { (mg kg }\end{array}$} \\
\cline { 2 - 5 } & $80{ }^{-1} \mathrm{C}$ & $90^{\circ} \mathrm{C}$ & $100{ }^{\circ} \mathrm{C}$ & $120^{\circ} \mathrm{C}$ \\
\hline $\begin{array}{l}\text { 4-Chloro-2-(trifluoromethyl)benzenamine } \\
\text { or similar }^{\mathrm{b}}\end{array}$ & 3.2 & 2.9 & 3.7 & 7.8 \\
\hline Dimethyl tetrasulfide $^{\mathrm{b}}$ & 2.0 & 2.2 & 3.2 & 3.6 \\
\hline${\text { Undetermined saturated hydrocarbon } \mathrm{C}_{14}}^{*}$ & 2.0 & 1.7 & 1.9 & 3.0 \\
\hline Tetradecane $^{\mathrm{b}}$ & 3.5 & 2.1 & 2.8 & 3.2 \\
\hline Indole $^{\mathrm{b}}$ & 1.2 & 0.95 & 1.1 & 0.85 \\
\hline Diphenyl ether $^{\mathrm{b}}$ & 0.45 & 0.47 & 0.71 & 0.88 \\
\hline Total VOCs $^{\mathrm{a}}$ & $\mathbf{5 9 1}$ & $\mathbf{5 9 1}$ & $\mathbf{5 4 5}$ & $\mathbf{5 6 1}$ \\
\hline
\end{tabular}

${ }^{a}$ Authentic quantitative standard.

${ }^{b}$ The coincidence between the experimental mass spectrum and the proposed compound mass spectrum of the NIST database was higher than $90 \%$. When the authentic standard was not available, the specific isomer was not differentiated or the most probable compound was indicated.

${ }^{c}$ The coincidence between the experimental mass spectrum and the proposed compound mass spectrum of the NIST database was $80-90 \%$. When the authentic standard was not available, the specific isomer was not differentiated or the most probable compound was indicated.

nd: Compound studied but not detected.

obtaining similar results, and therefore table 1 only shows the values for one of them. The compounds are arranged according to their retention times, and a superscript besides each name of compound indicates the method used for its identification and quantification (its meaning is shown at the end of the table).

The levels observed are high. It can be pointed out that the air was not recirculated in the runs, whereas this occurs at the thermal drying plants and therefore in that case the emissions levels could be higher when a purge is released after some recirculation.

Forty-five compounds were identified. The compounds with the highest yields at any temperature are dimethyl disulfide, toluene, dimethyl trisulfide and 1,2,4-trimethylbenzene in this order, with concentrations notably higher than the rest of compounds.

With respect to the type of compounds found, the high quantity of chlorinated and non-chlorinated aromatic hydrocarbons is remarkable, and many of them can be toxic. Among the chlorinated ones, the occurrence of 4-chloro-2(trifluoromethyl)benzenamine or similar compound can be highlighted. This specific benzenamine is commonly used commercially as an intermediate compound for the preparation of colorants, although the trifluoromethyl substituted benzenamines, in general, are moreover used as intermediate substances for the production of pesticides. On the other hand, aliphatic 
hydrocarbons were also found, most of them non-chlorinated, and some of them with oxygenated functional groups.

Other important compounds are dimethyl disulfide, trisulfide and tetrasulfide, responsible for the characteristic and strong smell of the sludge, and produced by the metabolic activity of the bacteria in amino acids with sulphur groups, from protein and peptide degradation.

Most compounds are harmful by inhalation and/or toxic [8,9], such as chlorobenzene, isopropylbenzene or dimethyl disulfide. It must be pointed out that dimethyl disulfide, a toxic compound, was found in high concentrations. Furthermore, some of them are possible carcinogen, such as 1,4dichlorobenzene, naphthalene or compounds similar to 4-chloro-2(trifluoromethyl)benzenamine. This fact necessitates the control of the gases emitted during the thermal drying of sludge at a plant, even if a deodorization system is used.

With respect to the temperature effect, the total yields in the four experiments were very similar and the identified compounds were practically the same. Therefore, it can be said that the temperature does not have a significant effect on the compounds emitted, which is a logical result. Concerning the individual compounds, some of them increase their levels at a higher temperature but with slight variations, such as 4-chloro-2-(trifluoromethyl)benzenamine, dimethyl tetrasulfide, dichlorotoluenes or propyltoluenes.

Regarding the blank sample, several compounds as toluene, ethylbenzene or xylenes were found, although their concentrations were much lower than those obtained in the experiments with sludge. Nevertheless, this has been taken into account to quantify the compounds in the samples studied.

In the literature, no research about VOCs during the thermal drying of sludge has been found up to now. However, several studies have been done about the occurrence of VOCs in sewage sludge directly. Wilson et al. [2] observed total concentrations of 4.62-568 $\mathrm{mg} \mathrm{kg}^{-1} \mathrm{~d} . \mathrm{w}$. after analysing twelve samples, where the highest value was very close to the concentrations obtained in this work (table 1) for the four drying temperatures. The most abundant compound was toluene, and also high levels of xylenes and ethylbenzene were reported, although in that study a small quantity of compounds was analysed (sixteen VOCs) without considering, for instance, the compounds with sulphur. There was no apparent connection between the concentration of the VOCs obtained and the volume of industrial wastewater treated at the WWTP source of the sludge. In the present work, significant concentrations of the compounds mentioned by Wilson et al. [2] have been observed during the drying of sewage sludge. On the other hand, Webber et al. [3] studied a higher number of compounds, twenty-six VOCs, and the results agree with the previous authors, obtaining total concentrations higher than $5 \mathrm{mg} \mathrm{kg}^{-1}$, where toluene and xylenes predominated.

Other authors have studied the emissions of VOCs during sludge dewatering processes by centrifuges and filter press. Monteith and Bell [10] observed the important presence of toluene, xylenes, ethyltoluenes, trimethylbenzenes and 1,4-dichlorobenzene in air collected from the processes, although most VOCs remained in the solid and the emissions to the air were considered low. The 
dewatering process is carried out at environmental temperature, whereas the thermal drying is done at higher temperatures and therefore the emissions by evaporation must be also higher.

\section{Conclusions}

The main conclusions extracted from the results obtained are the following:

- High concentrations of VOCs were found in the air from thermal drying of sewage sludge, some of them toxic, and therefore there is a need to control the emissions from the drying plants.

- The temperature does not have a significant effect on the number of identified compounds nor on the total yield of VOCs found, only a slight effect on some yields of individual compounds.

\section{Acknowledgement}

Support for this work was provided by project CTQ2005-05262 (Ministerio de Educación y Ciencia, Spain).

\section{References}

[1] Monteith, H. \& Parker, W., VOC emissions from biosolid's dewatering processes. Emissions from Wastewater Treatment Plants, ed. P. Tata, J. Witherspoon \& C. Lue-Hing, CRC Press: Boca Raton (Florida), pp. 171188, 2003.

[2] Wilson, S.C., Burnett, V., Waterhouse, K.S. \& Jones, K.C., Volatile organic compounds in digested United Kingdom sewage sludges, Environmental Science \& Technology, 28(2), pp. 259-266, 1994.

[3] Webber, M.D., Rogers, H.R., Watts, C.D., Boxall, A.B.A., Davis, R.D. \& Scoffin, R., Monitoring and prioritisation of organic contaminants in sewage sludges using specific chemical analysis and predictive, nonanalytical methods, Science of the Total Environment, 185(1-3), pp. 27-44, 1996.

[4] Suschka, J., Mrowiec, B. \& Kuszmider, G., Volatile organic compounds (VOC) at some sewage treatment plants in Poland, Water Science and Technology, 33(12), pp. 273-276, 1996.

[5] US EPA, Method 0031: Sampling method for volatile organic compounds (SMVOC). Test Methods for Evaluating Solid Waste, Physical/Chemical Methods (SW-846), U.S. Environmental Protection Agency's Office of Solid Waste: Washington, 18 pp., 1996.

[6] US EPA, Method 5041A: Analysis for desorption of sorbent cartridges from volatile organic sampling train (VOST). Test Methods for Evaluating Solid Waste, Physical/Chemical Methods (SW-846), U.S. Environmental Protection Agency's Office of Solid Waste: Washington, 20 pp., 1996. 
[7] US EPA, Method 8260B: Volatile organic compounds by GC/MS. Test Methods for Evaluating Solid Waste, Physical/Chemical Methods (SW846), U.S. Environmental Protection Agency 's Office of Solid Waste: Washington DC, 86 pp., 1996.

[8] Merck Safety Data Sheets (MSDS), http://www.merck-chemicals.com/isbin/INTERSHOP.enfinity/WFS/Merck-International-Site/en_US//USD/ViewSearch-SearchFormMSDS

[9] Physical and Theoretical Chemistry Laboratory, Oxford University, Chemical and Other Safety Information, http://physchem.ox.ac.uk/MSDS/

[10] Monteith, H. \& Bell, J.O., Modelling of VOC emissions from biosolids dewatering processes. Proceedings WEFTEC 98: $71^{\text {st }}$ ANNUAL CONFERENCE AND EXPOSITION, vol. 6, Orlando, pp. 157-168, 1998. 